\title{
Analysis of Direct and Indirect Selection and Indices in Bread Wheat (Triticum aestivum L.) Segregating Progeny
}

\author{
Zine El Abidine Fellahi $\mathbb{D}^{1},{ }^{1}$ Abderrahmane Hannachi, ${ }^{2}$ and Hamenna Bouzerzour ${ }^{3}$ \\ ${ }^{1}$ Department of Agronomy, Faculty of Natural, Life and Earth Sciences and the Universe, \\ University of Mohamed El Bachir El Ibrahimi, 34034 Bordj Bou Arréridj, Algeria \\ ${ }^{2}$ National Agronomic Research Institute of Algeria (INRAA), Unit of Sétif, 19000 Sétif, Algeria \\ ${ }^{3}$ Department of Ecology and Plant Biology, Valorization of Natural Biological Resources Laboratory, \\ Faculty of Natural and Life Sciences, University of Ferhat Abbas Sétif-1, 19000 Sétif, Algeria \\ Correspondence should be addressed to Zine El Abidine Fellahi; zinou.agro@gmail.com
}

Received 27 December 2017; Accepted 5 March 2018; Published 19 April 2018

Academic Editor: Iskender Tiryaki

Copyright (C) 2018 Zine El Abidine Fellahi et al. This is an open access article distributed under the Creative Commons Attribution License, which permits unrestricted use, distribution, and reproduction in any medium, provided the original work is properly cited.

\begin{abstract}
Three selection methods including direct and indirect selection along with selection index based on the phenotypic values of eleven traits of agronomic interest were assessed for their application in $\mathrm{F}_{4}$ bread wheat progenies. Significant genetic variation existed among parents and crosses for the traits measured. The following were the most efficient indices for simultaneous selection of superior lines for yield and its components: base index of Williams, followed by the sum of ranks index of Smith and Hazel. The selection-based index provided the highest grain yield gains as compared to the other selection criteria, except for flag leaf area, indicating that the direct and indirect monotrait selection were not appropriate in the situation analyzed in this work. PCA identified Ain Abid $\times$ Mahon-Demias, Ain Abid $\times$ Rmada, and Ain Abid $\times$ El-Wifak as the most promising populations. At 5\% selection intensity, the top 30 lines selected were distinguished, in comparison with the standard check Hidhab, by significant improvements in yield and yield components.
\end{abstract}

\section{Introduction}

In Algeria, most of wheat producing areas are located in the High Plateaus which are characterized by cold winters, insufficient and erratic rainfall, frequent spring frosts, and late-season sirocco occurrence $[1,2]$. In addition to these climatic stresses, there are some other technical constraints that essentially arise from the use of unproductive varieties and often bad agronomic practices. Selection for a better adaptation to environmental stresses is, therefore, more promising outcome in the field of wheat breeding. Breeders are continually seeking to improve the selection methods in order to develop superior wheat varieties with high grain yield, good end-use quality, and tolerance to biotic and abiotic stresses.

Direct selection based on grain yield is mainly practiced in wheat breeding programs without considering the adaptive traits that are crucial production regulators under variable environments [3-5]. In these environments, the presence of genotype $\times$ environment interactions reduces the efficiency of using grain yield as the sole selection criterion and, thus, complicates the efforts of selection [6,7]. In addition to the environmental effects, other factors such as polygenic nature, low heritability of grain yield, linkage, and nonadditive gene action may make the selection less efficient mainly in early segregating generations.

In order to overcome these difficulties, breeders are focusing on other traits that can be used in parallel or independently of yield in a multitraits approach. Indirect selection uses some yield components that are more heritable than yield itself and more stable in relation to genetic and environmental factors affecting them. When these components are measured without error and expressed in appropriate units, their product is yield. This has created new opportunities for plant breeders to use certain morphological, physiological, and biochemical traits during selection for grain yield. In the literature, several authors have reported the use of many of 
these traits to improve grain yield in diverse environments [8-10].

Selection-based index is another approach, certainly complex, but can avoid the limits of the single-trait selection, particularly the undesirable between-trait relations that present an additional nuisance in breeders' work [11]. Selection-based index approach targets the simultaneous improvement of several traits at the same time, including the grain yield $[12,13]$. The indices allow the use of a single value in the selection process, since the analysis is carried out by means of linear combinations of phenotypic data of different traits of agronomic interest with the genetic properties of a population [14]. The objective is to guarantee the improvement of the population genotypic values and consequently the efficiency of the selection process, maximizing the expected genetic gain. In this purpose, many selection indices have been used as an effective selection criterion in plant breeding programs on different crops [15]. However, the conditions determining the usefulness of an appropriate selection index may vary with individual plant breeder. The objective of this research paper was to evaluate the efficiency and applicability of different selection criteria based on the estimation of genetic gain in $\mathrm{F}_{4}$ segregating populations of bread wheat evaluated under semiarid conditions.

\section{Materials and Methods}

2.1. Plant Material and Experimental Design. This experiment had 609 genotypes, comprising $20 \mathrm{~F}_{4}$-derived families and their 9 parents. The history of these families is that, after the initial crosses in 2010/11 [18], $30 \mathrm{~F}_{2}$ lines were selected in each family by using pedigree method and were evaluated during the 2012/13 cropping season [19]. A total of 600 lines were planted and harvested in bulk during two consecutive growing seasons 2013/14 and 2014/15. The $\mathrm{F}_{4}$ lines along with their parents were planted in Sétif Research Unit $\left(36^{\circ} 15^{\prime} \mathrm{N} ; 5^{\circ} 87^{\prime} \mathrm{E} ; 1081\right.$ masl) of the Algerian National Institute of Agronomic Research (INRAA) in a modified randomized complete block design with three replications. The experimental unit consisted of a single row plot of $2 \mathrm{~m}$ length with rows spaced $0.2 \mathrm{~m}$ apart. The plots were fertilized with $100 \mathrm{~kg} \mathrm{ha}^{-1}$ of $46 \%$ superphosphate, before sowing, and $75 \mathrm{~kg} \mathrm{ha}^{-1}$ of $35 \%$ urea, at tillering stage. Weed control was performed chemically using $12 \mathrm{~g} \mathrm{ha}^{-1}$ of the Granstar [tribenuron methyl] herbicide. According to Chennafi et al. [20], the climate of the region is a semiarid type, continental with cold winter and hot and dry summer. Total annual rainfall is around $350 \mathrm{~mm}$. The soil used was classified as a silty clay with high $\mathrm{CaCO}_{3}$ content [20].

2.2. Measurements. The following traits were measured as per plot basis. Chlorophyll content (CHL, Spad) was determined at heading stage using the SPAD-502 chlorophyll meter (Minolta Camera Co., Osaka, Japan). Flag leaf area (FLA, $\mathrm{cm}^{2}$ ) was obtained using the formula described by Spagnoletti Zeuli and Qualset [21]: FLA $\left(\mathrm{cm}^{2}\right)=L(\mathrm{~cm}) \times l(\mathrm{~cm})$, where $L$ is the flag leaf length and $l$ refers to the flag leaf width. Heading date (HD, days) was recorded as the number
TABLE 1: The skeleton of the analysis of variance.

\begin{tabular}{lccc}
\hline Source of variation & $\mathrm{df}$ & MS & $F$-test \\
\hline Block & $b-1$ & $M 1$ & $M 1 / M 6$ \\
Genotype & $g-1$ & $M 2$ & $M 2 / M 6$ \\
$\quad$ Parents & $P-1$ & $M 3$ & $M 3 / M 6$ \\
$\quad \mathrm{~F}_{4}$ & $n-1$ & $M 4$ & $M 4 / M 6$ \\
$\quad$ Parents vs. F & 1 & $M 5$ & $M 5 / M 6$ \\
Residual & $(g-1)(b-1)$ & $M 6$ & -- \\
\hline Total & $b g-1$ & -- & -- \\
\hline
\end{tabular}

of calendar days from January first to the date when $50 \%$ of the spikes were half way out from flag leaf. Plant height $(\mathrm{PH}, \mathrm{cm})$ was measured at maturity from the soil surface to the top of the spike, awns excluded. Above ground biomass (BIO, $\mathrm{g} \mathrm{m}^{-2}$ ) was estimated from a harvested area of $0.5 \mathrm{~m}$ long $\times 0.20 \mathrm{~m}$ interrow spacing, which served also to obtain the grain yield $\left(\mathrm{GY}, \mathrm{g} \mathrm{m}^{-2}\right)$, number of spikes $\left(\mathrm{SN}, \mathrm{m}^{-2}\right.$ ), and spikes weight (SW, $\mathrm{g} \mathrm{m}^{-2}$ ). 1000-kernel weight (TKW, g) was obtained from the count and weight of 250 -kernel. The number of grains per spike (GN) was derived from estimated values of grain yield, number of spikes, and 1000-kernel weight. Harvest index (HI, \%) was estimated by the ratio between grain yield and above ground biomass.

2.3. Data Analysis. Data collected were subjected to analysis of variance following the procedures described by McIntosh [22]; the skeleton of the analysis of variance is shown in Table 1. The statistical model used considered the complete randomized block design as $Y_{i j}=\mu+g_{i}+b_{i}+\varepsilon_{i j}$, where $Y_{i j}$ is the observation of the $i$ th genotype, evaluated in the $j$ th replicate; $\mu$ is the overall mean of the experiment; $g_{i}$ is the effect of the $i$ th genotype; $b_{j}$ is the effect of the $j$ th block; and $\varepsilon_{i j}$ is the effect of the $i j$ th plot.

In case $F$-test was significant, standard error and critical differences were calculated by using the least significant difference test at 0.05 probability level (LSD0.05) according to Steel and Torrie [23]: LSD0.05 $=t_{0.05} \sqrt{2 \sigma_{e}^{2} / b}$, where $t_{0.05}$ is the tabulated value of the $t$-test at 0.05 probability level for $(g-1)(b-1)$ residual degrees of freedom; $\sigma^{2}{ }_{e}$ is the residual variance; and $b$ refers to the number of replications or blocks.

The genotypic variance $\left(\sigma_{g}^{2}\right)$ and residual variance $\left(\sigma_{e}^{2}\right)$ were calculated and served to determine the following genetic and nongenetic parameters for each trait. The coefficient of experimental variation $(\mathrm{CV})$ was calculated by $\mathrm{CV}(\%)=$ $\sqrt{\sigma_{e}^{2}} / \bar{X}$, where $\sigma^{2}{ }_{e}$ is the residual variance and $\bar{X}$ is the general mean of the trait. The coefficient of genetic variation $\left(\mathrm{CV}_{g}\right)$ was calculated by the following equation: $\mathrm{CV}_{g}(\%)=\sqrt{\sigma_{g}^{2}} / \bar{X}$, where $\sigma_{g}^{2}$ is the genotypic variance and $\bar{X}$ is the general mean of the trait. The variation index was determined as the ratio of $\mathrm{CV}_{g} / \mathrm{CV}_{e}$. Broad-sense heritability of average progenies $\left(h^{2}{ }_{\text {bs }}\right)$ was estimated by the expression [24]: $h_{\mathrm{bs}}^{2}(\%)=100 \times$ $\left[\sigma_{g}^{2} /\left(\sigma_{g}^{2}+\sigma_{e}^{2}\right)\right]$. Narrow-sense heritability of individuals within families $\left(h^{2}{ }_{n s}\right)$ was determined based on the parent-offspring 
regression. To do so, two methods were used: the first was by the linear regression of $\mathrm{F}_{4}$ on the parental $\mathrm{F}_{3}$ individual values [16], while the second approach was performed with standardized data of offspring $\left(\mathrm{F}_{4}\right)$ versus standardized of the corresponding parent $\left(\mathrm{F}_{3}\right)$ according to Frey and Horner [17].

The selection gains were estimated among families based on three selection criteria: direct selection, indirect selection, and selection-based index considering the selection intensity of $5 \%$ of top families. The expected gains by direct selection for each trait evaluated were estimated by the expression [25]: $\Delta G_{i}=h_{i}^{2} \times S_{i}=h^{2}{ }_{i} \times\left(\bar{X}_{s i}-\bar{X}_{0 i}\right)$, where $\Delta G_{i}$ is the gain with the direct selection carried for the $i$ th trait; $h^{2}{ }_{i}$ is the heritability of the $i$ th trait; $S_{i}$ refers to the differential selection of the $i$ th trait; $\bar{X}_{s i}$ is the mean of the $i$ th trait for the selected individuals; and $\bar{X}_{0 i}$ is the mean of the $i$ th trait in the base population. The expected gain of direct selection, expressed as a percentage of the population mean, is given by $\Delta G_{i i} \%=\left(\Delta G_{i} \times 100\right) / \bar{X}_{0 i}$.

Gains from indirect response to selection were calculated using the following expression [25]: $\mathrm{GS}_{j(i)}=h^{2}{ }_{j} \times\left(\bar{X}_{i j}-\right.$ $\left.\bar{X}_{0 j}\right)=h^{2}{ }_{j} \times \mathrm{DS}_{j(i)}$, where $\mathrm{GS}_{j(i)}$ is the gain on the $j$ th trait, with selection based on the $i$ th trait; $\bar{X}_{s j}$ is the mean of the $j$ th trait for the selected individuals based on the $i$ th trait; $\bar{X}_{0 j}$ is the mean of the $j$ th trait; $h^{2}{ }_{j}$ is the heritability of the $j$ th trait; and DS $S_{j(i)}$ refers to the differential selection of the $j$ th trait, in which the selected lines presented the best performance for the $i$ th trait. The expected gain of indirect selection, expressed as a percentage of the population mean, is given by $\mathrm{GS}_{j(i)} \%=\left(\mathrm{GS}_{j(i)} \times 100\right) / \bar{X}_{0 i}$.

For the selection-based index, the following methodologies were used for gains estimation: the classic index proposed by Smith [26] and Hazel [27], the base index of Williams [28], the free weights and parameters index of Elston [29], the index of desired gains of Pesek and Baker [30], the multiplicative index of Subandi et al. [31], the sum of ranks index of Mulamba and Mock [32], and the genotype-ideotype distance index proposed by Cruz [25]. Each index displays certain particularities in its calculations and, as such, application is generally laborious due to the need to assign adequate economic weights to each trait. Based on the different analytical procedures of selection, the best populations were identified and the gains from selection were calculated. All statistical analyses were carried out using Genes software [33] and a Microsoft Excel ${ }^{\oplus}$ spreadsheet.

\section{Results and Discussion}

3.1. Genetic Variability and Heritability. The analysis of variance revealed significant genotype effect for almost all the traits under study except for flag leaf area and grain yield, which were not significant at 0.05 probability level (Table 2 ). This provides evidence of the presence of sufficient genetic variability among parents and hybrids that can be exploited in wheat breeding program through selection. Partitioning the genotype effect indicated significant differences between all parents for HD, PH, SN, TKW, SW, GN, BIO, and HI, and significant interpopulation differences for $\mathrm{HD}, \mathrm{PH}$, and GN. The contrast "Parents versus $\mathrm{F}_{4}$," was highly significant for $\mathrm{HD}, \mathrm{PH}$, and $\mathrm{SN}$, while the $\mathrm{F}_{4}$ populations exhibited significant differences for nearly all the observed quantitative phenotypic traits, except for CHL, FLA, GN, and HI, which were not significant at the $5 \%$ probability level. The results of this study corroborate those of Abd El-Shafi [34], who reported significant and highly significant differences among genotypes (families + parents) and families for all studied traits across three segregating generations $\mathrm{F}_{2}, \mathrm{~F}_{3}$, and $\mathrm{F}_{4}$. This author, also, reported that greater response to selection can be expected from selection in cross having greater phenotypic and genotypic variances.

The coefficient of variation (CV) presented values between 0.7 and $26.8 \%$ for heading date and grain yield, respectively (Table 2). The CV above $20 \%$ is considered high, indicating high dispersion of the experimental data, which may have been caused by the genetic and phenotypic differences between the studied materials. High CV estimate obtained for grain yield can be explained by the fact that it is quantitative trait, governed by several genes and highly influenced by the environment.

The variances values, coefficient of variation, and genetic parameters estimates for wheat traits studied are presented in Table 3. Broad-sense heritability is the proportion of total phenotypic variation due to all genetic effects. The knowledge of the genotypic determination coefficient $\left(h^{2}\right.$ bs $)$ allows establishing an estimate of the genetic gain to be obtained and defines the best strategy to be used in the plant breeding program [35]. In this study, the estimated broad-sense heritability varied from 0.00 to $91.80 \%$. The highest values were found for heading date $(91.80 \%)$ followed by plant height (80.82\%), 1000 -kernel weight $(72.90 \%)$, biomass $(65.33 \%)$, and number of grains per spike $(61.64 \%)$, indicating that these traits are highly heritable among the genotypes evaluated. These results can be confirmed with the values obtained by the $\mathrm{CV}_{g} / \mathrm{CV}_{e}$ ratio that were close to or greater than 1 for these traits, suggesting satisfactory conditions for selection [36]. Moderate estimates of $h^{2}$ bs occurred for the number of chlorophyll contents $(40.31 \%)$, number of spikes $(52.00 \%)$, spikes weight $(54.85 \%)$, and harvest index (40.67\%). On the other hand, the lowest values of $h_{\text {bs }}^{2}$ were found for the flag leaf area $(0.00 \%)$ and grain yield (19.39\%). These traits exhibited also low $\mathrm{CV}_{g} / \mathrm{CV}_{e}$ ratio values, indicating the dominant effect of the environment on crop.

Generally, literature indicates widely varying narrowsense heritability estimates. Mesele et al. [37] reported high heritability values for days to heading, days to maturity, and 1000-kernel weight; moderate estimates for grain filling period, spike length, number of spikelets per plant, grains per spike, and harvest index; and low values for number of tillers per plant, biomass yield and grain yield. Evaluating seven $\mathrm{F}_{2}$ populations derived through cross combinations of five parental varieties/lines of bread wheat, Saleem et al. [38] found low to high broad-sense heritability values ranging from $4.75 \%$ to $92.6 \%$ depending on the trait and the cross. The findings of Yaqoob [39] showed that heritability estimates were low for number of tillers per plant $(20 \%)$, grains per spike $(26.81 \%)$, days to maturity $(30.13 \%)$, spike length (36.66\%), and 1000 -kernel weight $(38.68 \%)$, moderate for plant height $(45.79 \%)$, and high for heading date $(84.73 \%)$ 
TABLE 2: Analysis of variance of different bread wheat traits studied.

\begin{tabular}{|c|c|c|c|c|c|c|c|}
\hline SV & Bloc & Genotypes & Parents & $\mathrm{F}_{4}$ & Parents versus $\mathrm{F}_{4}$ & Error & CV (\%) \\
\hline $\mathrm{df}$ & 2 & 28 & 8 & 19 & 1 & 56 & \\
\hline CHL & 8.6 & $19.0^{* *}$ & $9.5^{\mathrm{ns}}$ & $23.8^{* *}$ & $3.6^{\mathrm{ns}}$ & 8.6 & 6.6 \\
\hline HD & 1.5 & $9.0^{* *}$ & $18.3^{* *}$ & $2.5^{* *}$ & $58.7^{* *}$ & 0.7 & 0.7 \\
\hline FLA & 89.4 & $11.1^{\mathrm{ns}}$ & $6.9^{\mathrm{ns}}$ & $6.6^{\mathrm{ns}}$ & $0.1^{\mathrm{ns}}$ & 14.9 & 20.4 \\
\hline $\mathrm{PH}$ & 9.1 & $86.3^{* *}$ & $103.0^{* *}$ & $80.0^{* *}$ & $72.6^{*}$ & 16.6 & 6.3 \\
\hline $\mathrm{SN}$ & 1183.1 & $11187.5^{* *}$ & $26092.4^{* *}$ & $2657.8^{\text {ns }}$ & $53994.5^{* *}$ & 5371.1 & 15.9 \\
\hline TKW & 33.5 & $28.2^{* *}$ & $39.4^{* *}$ & $12.7^{\mathrm{ns}}$ & $232.1^{* *}$ & 7.7 & 7.4 \\
\hline SW & 117034.6 & $44873.6^{* *}$ & $74490.4^{* *}$ & $18248.8^{\mathrm{ns}}$ & $313746.3^{* *}$ & 20259.8 & 20.9 \\
\hline GN & 36.6 & $44.7^{* *}$ & $61.3^{* *}$ & $37.0^{*}$ & $41.0^{\mathrm{ns}}$ & 17.1 & 16.8 \\
\hline $\mathrm{BIO}$ & 81189.5 & $131077.4^{* *}$ & $243142.1^{* *}$ & $43601.7^{\mathrm{ns}}$ & $896559.2^{* *}$ & 45440.8 & 18.5 \\
\hline GY & 34149.2 & $15727.9^{\mathrm{ns}}$ & $26835.4^{\mathrm{ns}}$ & $11096.5^{\mathrm{ns}}$ & $56205.9^{*}$ & 12677.8 & 26.8 \\
\hline $\mathrm{HI}$ & 122.2 & $62.3^{*}$ & $136.6^{* *}$ & $36.1^{\mathrm{ns}}$ & $21.4^{\mathrm{ns}}$ & 37 & 16.8 \\
\hline
\end{tabular}

CHL: chlorophyll content (Spad), HD: heading date (days), FLA: flag leaf area $\left(\mathrm{cm}^{2}\right)$, PH: plant height (cm), SN: number of spikes, TKW: 1000-kernel weight (g), SW: spikes weight $\left(\mathrm{g} \mathrm{m}^{-2}\right)$, GN: number of grains per spike, BIO: above ground biomass $\left(\mathrm{g} \mathrm{m}^{-2}\right)$, GY: grain yield $\left(\mathrm{g} \mathrm{m}^{-2}\right)$, HI: harvest index (\%), and $\mathrm{ns}$, $*$, and $* *$ : nonsignificant and significant effect at 0.05 and 0.01 probability.

TABLE 3: Genetic and nongenetic parameters of different bread wheat traits studied.

\begin{tabular}{lcccccccc}
\hline Traits & $\sigma_{p}^{2}$ & $\sigma_{e}^{2}$ & $\sigma_{g}^{2}$ & $h_{\text {bs }}^{2}$ & $h^{2}{ }_{\mathrm{ns}}(\mathrm{SK})$ & $h^{2}{ }_{\mathrm{ns}}(\mathrm{FH})$ & $\mathrm{CV}_{g}(\%)$ & $\mathrm{CV}_{g} / \mathrm{CV}_{e}$ \\
\hline Chl & 3.36 & 2.00 & 1.35 & 40.31 & 28.55 & 30.13 & 2.64 \\
HD & 3.01 & 0.25 & 2.76 & 91.80 & 16.69 & 34.32 & 0.47 \\
FLA & 3.68 & 4.98 & 0.00 & 0.00 & 0.00 & 0.00 & 1.31 & 0.00 \\
PH & 28.78 & 5.52 & 23.26 & 80.82 & 27.27 & 27.27 & 7.43 & 0.00 \\
SN & 3729.17 & 1790.37 & 1938.79 & 52.00 & 0.00 & 0.00 & 9.59 & 0.19 \\
TKW & 9.41 & 2.55 & 6.86 & 72.90 & 31.64 & 25.99 & 6.98 & 0.95 \\
SW & 14957.91 & 6753.25 & 8204.67 & 54.85 & 8.66 & 10.70 & 13.19 & 0.64 \\
GN & 14.67 & 5.63 & 9.04 & 61.64 & 16.70 & 7.14 & 12.28 \\
BIO & 43692.45 & 15146.93 & 28545.52 & 65.33 & 3.37 & 5.93 & 14.48 \\
GY & 5242.64 & 4225.92 & 1016.71 & 19.39 & 10.13 & 12.31 & 0.73 \\
HI & 20.76 & 12.31 & 8.45 & 40.67 & 14.10 & 14.97 & 0.79 \\
\hline
\end{tabular}

CHL: chlorophyll content (Spad), HD: heading date (days), FLA: flag leaf area $\left(\mathrm{cm}^{2}\right)$, PH: plant height $(\mathrm{cm})$, SN: number of spikes, TKW: 1000-kernel weight (g), SW: spikes weight $\left(\mathrm{g} \mathrm{m}^{-2}\right)$, GN: number of grains per spike, BIO: above ground biomass $\left(\mathrm{g} \mathrm{m}^{-2}\right)$, GY: Grain yield $\left(\mathrm{g} \mathrm{m}^{-2}\right), \mathrm{HI}_{\text {: harvest index }(\%), h^{2}}{ }_{\text {bs }}$ : broad-sense heritability, $h^{2}$ ns (SK): narrow-sense heritability according to Smith and Kinman [16], and $h^{2}{ }_{n s}(\mathrm{FH})$ : narrow-sense heritability according to Frey and Horner [17].

and grain yield $(99.83 \%)$. His results also indicated that most of these traits exhibited low heritability under drought stress conditions, suggesting the presence of high genotype $\times$ environment interactions that affected the crop behavior.

Narrow-sense heritability is the proportion of the total phenotypic variation that is due to the additive effects of genes. This component of variation is important because it is the only variation that natural selection can act on. Hence, $h^{2}$ ns determines the resemblance of offspring to their parents and the population's evolutionary response to selection. There can be considerable nonadditive genetic variance, but this does not contribute to the resemblance between parents and offspring, or the response to selection. Low to moderate narrow-sense heritability values were recorded in this study. Chlorophyll content, heading date, plant height, 1000-kernel weight, and number of grains per spike recorded the highest estimates. These traits were less influenced by the environmental factors and would respond positively to a selection pressure in the current breeding program. The low heritability values can be explained by the change occurring in the segregating lines behavior from the precedent to the current generation. This change may be due to nonadditive gene action and/or high environmental factors effects.

Means of the variables measured showed that the best values varied depending on the cross and the trait, and the few populations had the best performances for several traits at the same time (Table 4 ). The best grain yielding population (557.5 g) was Ain Abid $\times$ El-Wifak which had also the highest average for the number of grains per spike (31.47 grains), spikes weight $(857.3 \mathrm{~g})$, above ground biomass (1350.3 g), and harvest index $(41.3 \%)$. Ain Abid $\times$ Hidhab cross combination had the longest vegetative cycle with an average of 127.8 days and presented the highest mean for the flag leaf area $\left(21.0 \mathrm{~cm}^{2}\right)$. Acsad $1069 \times$ El-Wifak had the highest average for the chlorophyll content (54.0 Spad). Acsad $_{1069} \times$ MahonDemias was the tallest $(75.23 \mathrm{~cm})$, while Acsad $_{1135} \times$ Rmada 


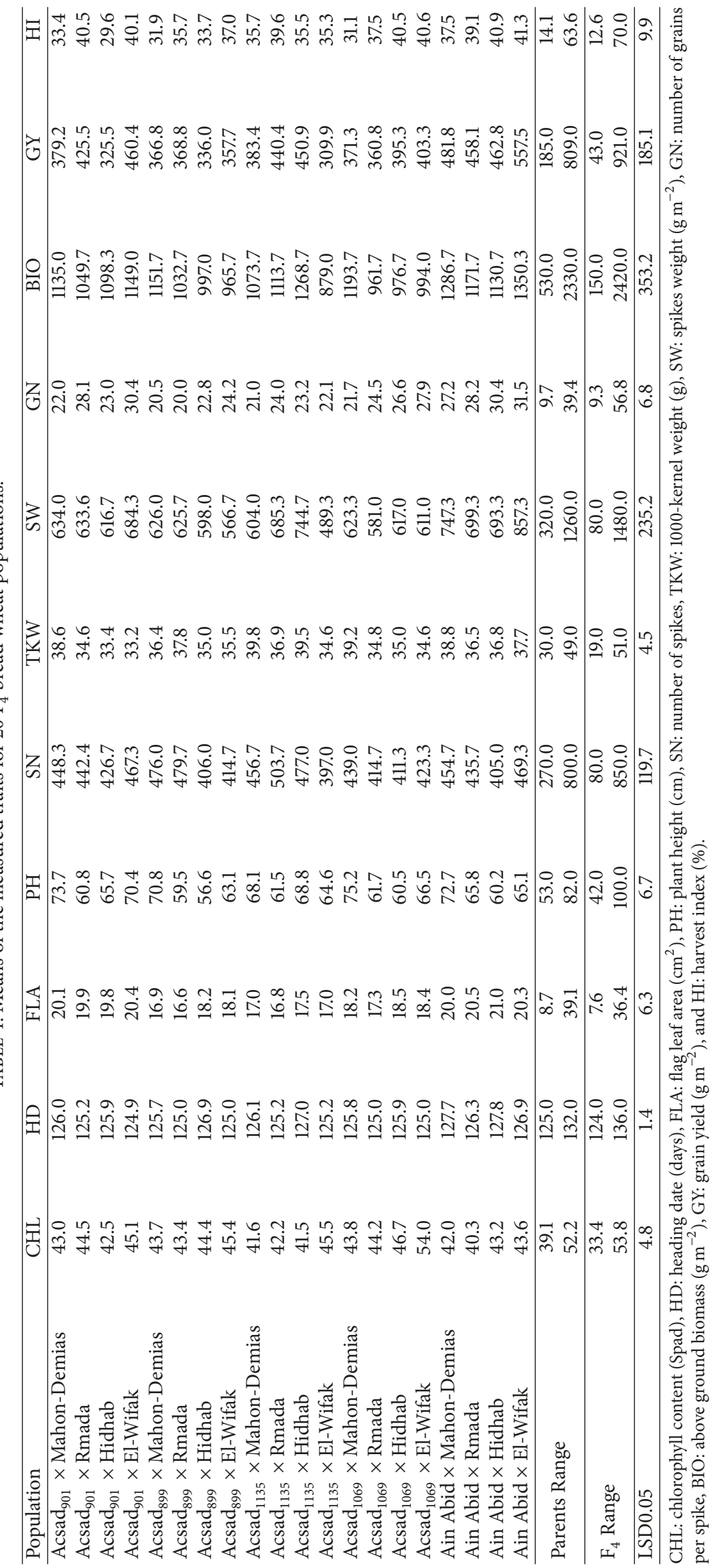


exhibited the highest average for the number of spikes (503.7 spikes). For 1000-kernel weight, Acsad $_{1135} \times$ Mahon-Demias was the best population with an average of $39.8 \mathrm{~g}$.

As the contrast "Parents versus $\mathrm{F}_{4}$ " was significant for $\mathrm{PH}, \mathrm{SN}, \mathrm{TKW}, \mathrm{SW}, \mathrm{BIO}$, and GY, and, compared with the least significant difference (LSD0.05), significant differences existed between the parents and hybrids values for these measured traits. These differences were 1 to 3 times higher than the LSD0.05 and were in favor of some $\mathrm{F}_{4}$ lines, indicating that they perform better than the parents and suggesting the possibilities of making significant changes through effective selection. These findings were in harmony with those obtained by Abd El-Shafi [34], Löffler and Busch [40], and Alexander et al. [41].

\subsection{Genetic Gain from Direct and Indirect Selection and} Selection-Based Index. The gains of direct and indirect selection are shown in Table 5. The results showed a big variation in the percentages of gains among the measured traits. The total sum of gains per selection varied from $-36.11 \%$ for heading date to $34.75 \%$ for flag leaf area. Generally, the direct selection based on chlorophyll content, heading date, spikes weight, grain yield, and harvest index resulted in negative total gains. On the other hand, flag leaf area, plant height, number of spikes, 1000-kernel weight, number of grains per spike, and biomass recorded positive total gains.

The gains obtained by direct selection were higher than those of indirect selection. But, sometimes the indirect selection may be more efficient, especially if the secondary trait is highly correlated with yield and is easily measurable [42]. The number of grains per spike (15.86\%) followed by above ground biomass (12.30\%), plant height (12.10\%), and number of spikes $(10.84 \%)$ exhibited the greatest gains from direct selection. Inversely, heading date $(-1.13 \%)$, spikes weight $(-4.99 \%)$ and harvest index $(-3.81 \%)$ showed negative gain values. Negative gain for heading date is desired in the case of this study as the Algerian wheat breeding program designed for semiarid regions; precocity is a crucial criterion adopted for selection. It is related to the ability of plants to shorten their cycle, so as to decrease their exposure to the late-season sirocco weathering.

The direct selection for chlorophyll content resulted in negative indirect gains for nearly all the other traits, except for the flag leaf area, number of grains per spike, and harvest index that showed positive responses. For heading date, the indirect selection gains were only positive for chlorophyll content, number of spikes, and harvest index. The correlative effects of the selection based on the flag leaf area were desirable for grain yield, although the indirect gain for the remaining traits was practically negative.

The direct selection for plant height resulted in positive indirect gains for heading date, number of spikes, 1000-kernel weight, and spikes weight. In addition, positive responses of the selection based on yield and yield components were observed for grain yield itself, heading date, 1000-kernel weight, and spikes weight. However, negative indirect gains were exhibited for other traits including chlorophyll content, flag leaf area, and number of grains per spike, indicating that indirect selection for one variable for gain in another is unfeasible, because there will be a loss in the indirectly selected variable. In cases of negative gains, the model is considered inappropriate for selection in this plant material.

The highest correlated responses for grain yield were generated though indirect selection on the base of the flag leaf area $\left(8.04 \%\right.$, i.e., $\left.33.87 \mathrm{~g} \mathrm{~m}^{-2}\right)$, followed by the spike fertility $\left(3.65 \%\right.$, i.e., $\left.15.39 \mathrm{~g} \mathrm{~m}^{-2}\right)$, 1000 -kernel weight $\left(3.63 \%\right.$, i.e., $\left.15.31 \mathrm{~g} \mathrm{~m}^{-2}\right)$, and above ground biomass $(2.74$, i.e., $11.54 \mathrm{~g} \mathrm{~m}^{-2}$ ). These results indicated that the indirect selection was to be more effective in improving the primary trait than the indirect selection based on other traits and/or on the direct selection based on the grain yield itself.

Several authors have estimated the genetic gains of traits involved in yield determination. The results are often inconsistent and scarce. Our results were consistent with those of DePauw and Shebeski [43] and Inagaki et al. [44], who mentioned that direct selection on the basis of yield is ineffective in early generations. Benmahammed et al. [45] reported the same findings in barley crop. Their results showed that biomass-based direct selection appeared more discriminating than yield-based selection in their plant material. However, the results of this study do not corroborate findings reported by Lalić et al. [11], Mitchell et al. [46], Lungu et al. [47], and El-Morshidy et al. [48] and who observed the effectiveness of the direct selection on grain yield. The difference in the results may be attributed to differences of breeding material and to genotype $\times$ environments.

The gains of selection-based index are shown in Table 6. The total sum of gains from the selection-based index ranged from $-9.37 \%$ to $42.86 \%$. Five out of seven used indices showed positive total gains. The base index of Williams recorded the highest total gain $(42.86 \%)$ followed by the classic index of Smith and Hazel, the index desired gains of Pesek and Baker (27.46\%), and the genotype-ideotype distance index of Cruz (22.07\%). The sum of ranks index of Mulamba and Mock had a very low gain of 3.74\%. Subandi's and Elston's indices exhibited negative total gains.

The base index of Williams yielded positive responses for all measured traits, except for chlorophyll content, flag leaf area, and harvest index, which showed negative gains. This index also achieved the highest grain yield response $(6.27 \%$, i.e., $26.41 \mathrm{~g} \mathrm{~m}^{-2}$ ) compared to the other indices employed in this study. The classic index of Smith and Hazel ranked second followed by the index of desired gains of Pesek and Baker, the genotype-ideotype distance index proposed by Cruz, and the sum of ranks index of Mulamba and Mock with selection responses of $36.93 \%, 27.46 \%, 22.07 \%$, and $3.74 \%$, respectively. The single-trait responses varied from one index to another with, a more or less, balanced distribution of positive and negative estimates among the traits. This shows that the monotrait selection was inadequate because it led to a higher final product when considering the grain yield and generated unfavorable responses in other traits. These results indicated that methods that combine favorable expected gains should be used in the evaluation of these progenies. The gains expected through indices for grain yield per se were larger than those obtained by direct and indirect monotrait selection, except for the flag leaf area (Tables 5 and 6). Mahdy [49] mentioned that selection-based index was predicted to be 


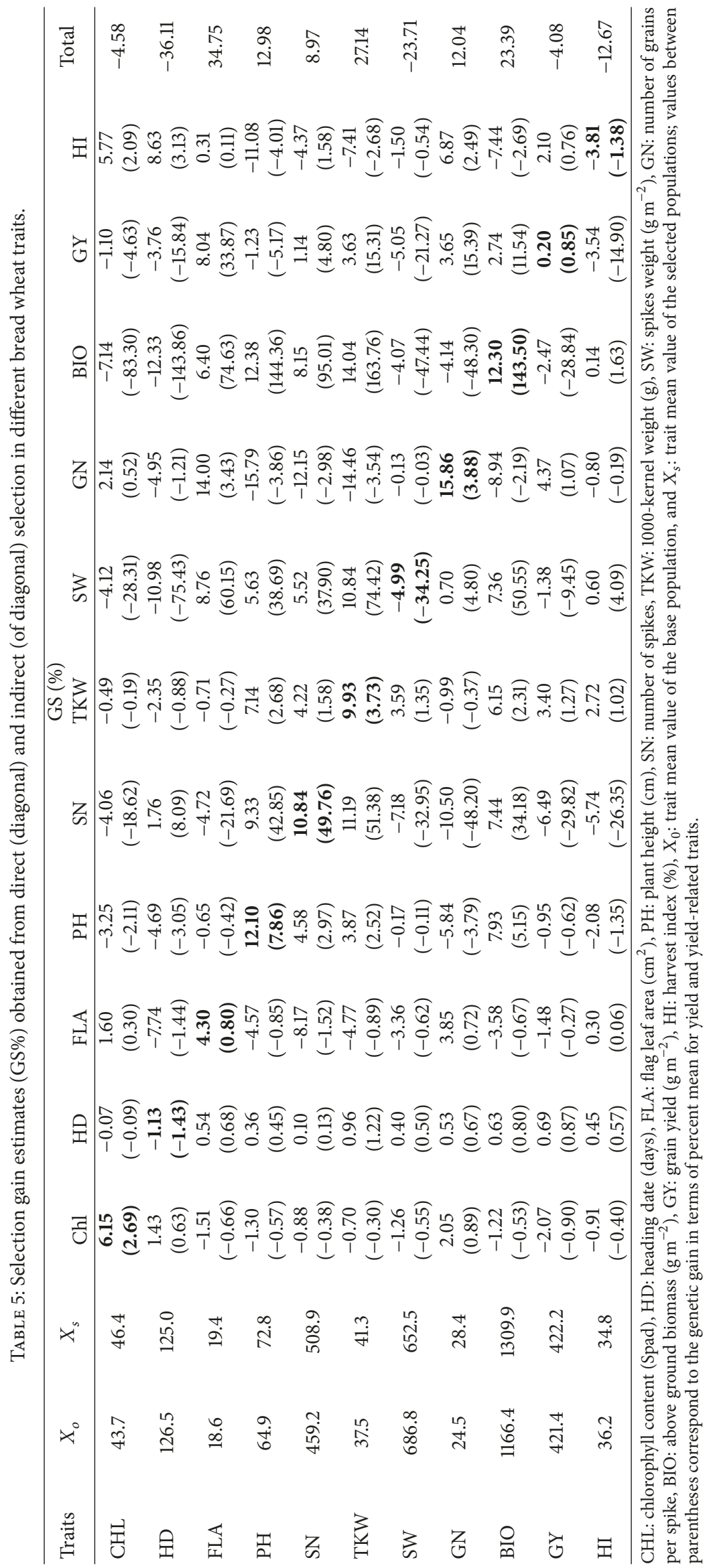




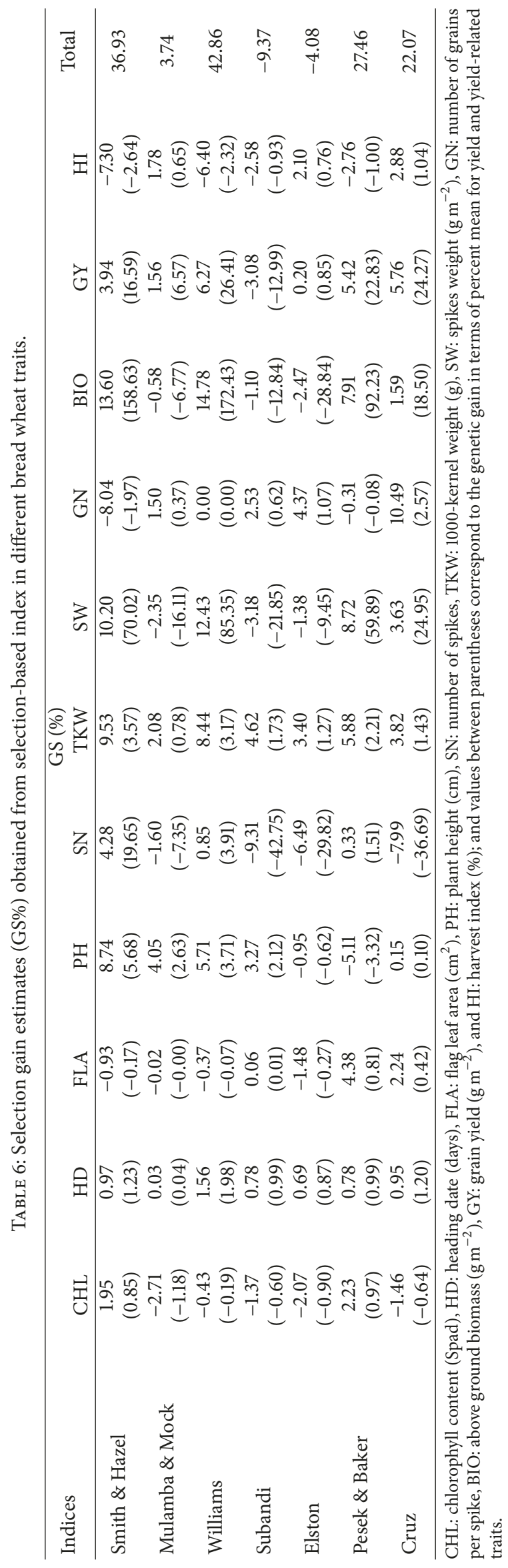


TABLE 7: Differences of the $\mathrm{F}_{4}$ selected lines relatively to the standard check Hidhab for the measured traits.

\begin{tabular}{|c|c|c|c|c|c|}
\hline Traits & $\mathrm{F}_{4}$ selected lines mean & Hidhab & Difference & Difference in \% of Hidhab & LSD0.05 \\
\hline Chl & 42.26 & 43.30 & -1.05 & -2.41 & 4.80 \\
\hline $\mathrm{HD}$ & 126.57 & 129.67 & $-3.10^{*}$ & -2.39 & 1.40 \\
\hline FLA & 19.15 & 19.40 & -0.24 & -1.26 & 6.31 \\
\hline $\mathrm{PH}$ & 68.67 & 62.33 & 6.33 & 10.16 & 6.67 \\
\hline $\mathrm{SN}$ & 615.67 & 463.33 & $152.33^{*}$ & 32.88 & 119.67 \\
\hline TKW & 39.97 & 38.33 & 1.63 & 4.26 & 4.53 \\
\hline SW & 1147.67 & 823.33 & $324.33^{*}$ & 39.39 & 235.17 \\
\hline GN & 31.57 & 24.83 & $6.75^{*}$ & 27.18 & 6.75 \\
\hline $\mathrm{BIO}$ & 1833.67 & 1376.67 & $457.00^{*}$ & 33.20 & 353.15 \\
\hline GY & 758.13 & 441.33 & $316.80^{*}$ & 71.78 & 185.10 \\
\hline HI & 41.78 & 32.23 & 9.55 & 29.63 & 9.94 \\
\hline
\end{tabular}

CHL: chlorophyll content (Spad), HD: heading date (days), FLA: flag leaf area $\left(\mathrm{cm}^{2}\right)$, PH: plant height $(\mathrm{cm})$, SN: number of spikes, TKW: 1000-kernel weight (g), SW: spikes weight $\left(\mathrm{g} \mathrm{m}^{-2}\right)$, GN: number of grains per spike, BIO: above ground biomass $\left(\mathrm{g} \mathrm{m}^{-2}\right)$, GY: grain yield $\left(\mathrm{g} \mathrm{m}^{-2}\right)$, and $\mathrm{HI}$ : harvest index $(\%)$. * Significant effect at 0.05 probability.

superior for yield improvement as compared to the monotrait selection method.

The first three axes of the Principal Component Analysis (PCA) explained more than $77.93 \%$ of the total variation available in the data subjected to analysis. Heading date $\left(0.386^{*}\right)$, flag leaf area $\left(0.308^{*}\right)$, spikes weight $\left(0.923^{*}\right)$, biomass $\left(0.853^{*}\right)$, and grain yield $\left(0.866^{*}\right)$ correlated significantly to PCA1. PCA2 was mainly related to the chlorophyll content $\left(0.276^{*}\right), 1000$-kernel weight $\left(0.440^{*}\right)$, number of grains per spike $\left(0.655^{*}\right)$, and harvest index $\left(0.547^{*}\right)$ (Figure 1). The number of spikes $\left(0.333^{*}\right)$ was related to PCA3 (Figure 2). The PCA biplots showed that the populations Acsad ${ }_{899} \times$ Hidhab (P7), Acsad A99 $_{89} \times$ El-Wifak (P8), Acsad ${ }_{1135} \times$ Hidhab (P11), Acsad $_{1135} \times$ El-Wifak (P12), Acsad Ang9 $_{10} \times$ Rmada (P14), Ain Abid $\times$ Mahon-Demias (P17), Ain Abid $\times$ Rmada (P18), and Ain Abid $\times$ El-Wifak (P20) were well represented on the plane formed by the first axis PCA1 (Figure 1).

Ain Abid $\times$ Mahon-Demias (P17), Ain Abid $\times$ Rmada (P18), and Ain Abid $\times$ El-Wifak (P20) had positive coordinates with this axis. They were characterized by a long vegetative cycle and high biomass, spikes weight, and grain yield values. The last two populations Ain Abid $\times$ Rmada (P18) and Ain Abid $\times$ El-Wifak (P20) were also distinguished by high values of chlorophyll content, flag leaf area, spikes fertility, and harvest index, relatively to PCA2 but were associated with low number of ears, relatively to PCA3 (Figures 1 and 2). On the other hand, Ain Abid $\times$ Mahon-Demias (P17) was distinguished, relatively to PCA2, by high estimates of the 1000-kernel weight and plant height, and associated with high number of spikes, relatively to PCA3 (Figures 1 and 2). From these results, it could be concluded that effective selection of superior individuals within this population certainly contributes to the improvement of yield and yield components, in a semi-late genetic background.

3.3. Selection of Superior Genotypes for Grain Yield. Genotypes were first ranked according to grain yield, then the 5\% highest yielding lines were selected, and their mean yield estimated. The 30 lines thus selected are derived from 15 out of 20 $\mathrm{F}_{4}$ populations studied. Half part of these lines was equitably

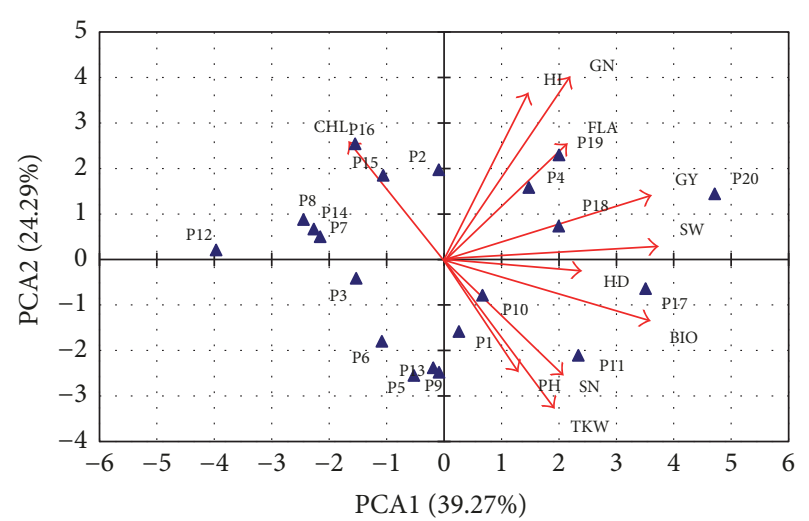

FIGURe 1: Principal Component Analysis (PCA) projections on axes 1 and 2 , accounting for $63.56 \%$ of total variation, for $20 \mathrm{~F}_{4}$ populations of bread wheat.

derived from Acsad $_{1135} \times$ Hidhab (P11), Ain Abid $\times$ Hidhab (P19), and Ain Abid $\times$ El-Wifak (P20) crosses. The population Ain Abid $\times$ Mahon-Demias (P17), previously identified among the promising populations, contributed with four lines. Acsad ${ }_{1069} \times$ Rmada (P14) and Ain Abid $\times$ Rmada (P18) participated with two lines each. Seven other populations contributed by one line each. Relative to the standard check Hidhab, which is the most cultivated variety in Algeria, the top 30 lines selected were characterized by significant improvements in yield components, including the number of spikes (152.33 spikes $\left.\mathrm{m}^{-2}\right)$, spikes weight $\left(324.33 \mathrm{~g} \mathrm{~m}^{-2}\right)$, spikes fertility ( 6.75 grains spike $\left.{ }^{-1}\right)$, above ground biomass $\left(457.00 \mathrm{~g} \mathrm{~m}^{-2}\right)$, and grain yield $\left(316.80 \mathrm{~g} \mathrm{~m}^{-2}\right)$ (Table 7). Besides, they were distinguished by significant reduction of the duration in the vegetative phase with 3.10 days (Table 7).

\section{Conclusion}

The results of this study indicated appreciable genetic variability among the evaluated populations. Selection based-index was more efficient to improve grain yield compared to direct 


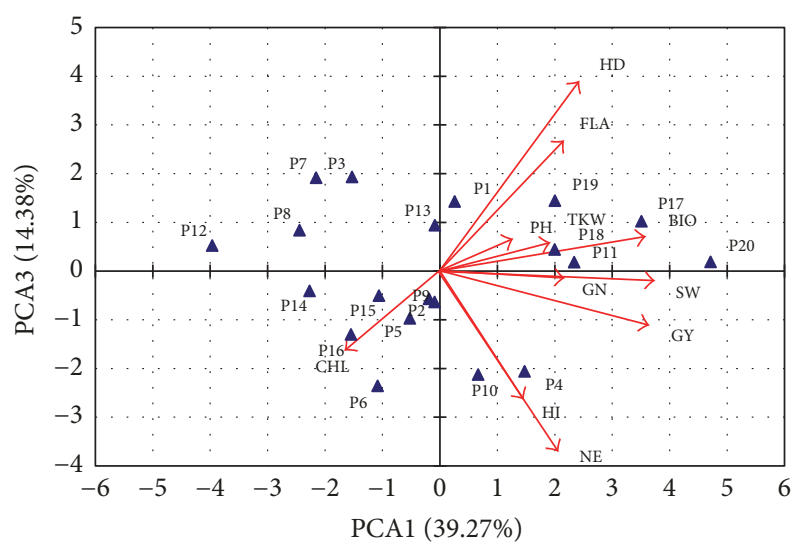

Figure 2: Principal Component Analysis (PCA) projections on axes 1 and 3 , accounting for $53.65 \%$ of total variation, for $20 \mathrm{~F}_{4}$ populations of bread wheat.

and indirect single-trait selection. The analytical procedures of the different selection methods showed possibilities of applications in advanced generations of breeding being superior when compared with direct and indirect selection. Williams's index was predicted to be more effective than the other selection indices for improving multiple traits at time. It brought the highest total genetic gain and the best yield gain per se associated with positive correlated responses for most of yield components. Compared to the check cultivar Hidhab, the $30 \mathrm{~F}_{4}$ selected lines, at $5 \%$ selection intensity, were characterized by significant increase in grain yield and yield related traits.

\section{Conflicts of Interest}

The authors declare that there are no conflicts of interest regarding the publication of this article.

\section{References}

[1] A. Benbelkacem, "Adaptation of cereal cultivars to extreme agroecologic environments of North Africa," Field Crops Research, vol. 45 , no. 1-3, pp. 49-55, 1996.

[2] A. Mekhlouf, F. Dehbi, H. Bouzerzour, A. Hannchi, A. Benmahammed, and A. Adjabi, "Relationships between cold tolerance, grain yield performance and stability of durum wheat (Triticum durum Desf.) genotypes grown at high elevation area of Eastern Algeria," Asian Journal of Plant Sciences, vol. 5, no. 4, pp. 700708, 2006.

[3] G. A. Slafer and F. H. Andrade, "Changes in physiological attributes of the dry matter economy of bread wheat (Triticum aestivum) through genetic improvement of grain yield potential at different regions of the world - A review," Euphytica, vol. 58, no. 1, pp. 37-49, 1991.

[4] S. P. Loss and K. H. M. Siddique, "Morphological and Physiological Traits Associated with Wheat Yield Increases in Mediterranean Environments," Advances in Agronomy, vol. 52, no. C, pp. 229-276, 1994.

[5] R. M. Trethowan, M. Van Ginkel, K. Ammar et al., "Associations among twenty years of international bread wheat yield evaluation environments," Crop Science, vol. 43, no. 5, pp. 1698-1711, 2003.
[6] H. Bouzerzour, A. Djekoun, A. Benmahammed, and K. L. Hassous, "Contribution de la biomasse aérienne, de l'indice de récolte et de la précocité à l'épiaison au rendement grain de l'orge (Hordeum vulgare L.) en zone d'altitude," Cahiers de l'Agriculture, vol. 8, pp. 133-137, 1998.

[7] A. Benmahammed, H. Nouar, L. Haddad, Z. Laala, A. Oulmi, and H. Bouzerzour, "Analyse de la stabilité des performances de rendement du blé dur (Triticum durum Desf.) sous conditions semi-arides," Biotechnologie, Agronomie, Société et Environnement, vol. 14, no. 1, pp. 177-186, 2010.

[8] B. R. Whan, R. Knight, and A. J. Rathjen, "Response to selection for grain yield and harvest index in F2, F3 and F4 derived lines of two wheat crosses," Euphytica, vol. 31, no. 1, pp. 139-150, 1982.

[9] M. P. Reynolds, R. P. Singh, A. Ibrahim, O. A. A. Ageeb, A. Larqué-Saavedra, and J. S. Quick, "Evaluating physiological traits to complement empirical selection for wheat in warm environments," Euphytica, vol. 100, no. 1-3, pp. 85-94, 1998.

[10] M. Balota, A. J. Green, C. A. Griffey, R. Pitman, and W. Thomason, "Genetic gains for physiological traits associated with yield in soft red winter wheat in the Eastern United States from 1919 to 2009," European Journal of Agronomy, vol. 84, pp. 76-83, 2017.

[11] A. Lalić, D. Novoselović, J. Kovačević et al., "Genetic gain and selection criteria effects on yield and yield components in barley (Hordeum vulgare L.)," Periodicum biologorum, vol. 112, no. 3, pp. 311-316, 2010.

[12] M. A. Babar, M. Van Ginkel, M. P. Reynolds, B. Prasad, and A. R. Klatt, "Heritability, correlated response, and indirect selection involving spectral reflectance indices and grain yield in wheat," Australian Journal of Agricultural Research, vol. 58, no. 5, pp. 432-442, 2007.

[13] M. M. Costa, A. O. Di Mauro, S. H. Unêda-Trevisoli et al., "Analysis of direct and indirect selection and indices in soybean segregating populations," Crop Breeding and Applied Biotechnology, vol. 8, no. 1, pp. 47-55, 2008.

[14] J. M. S. Viana, V. R. Faria, F. F. e Silva, and M. D. V. de Resende, "Combined selection of progeny in crop breeding using best linear unbiased prediction," Canadian Journal of Plant Science, vol. 92, no. 3, pp. 553-562, 2012.

[15] C. Y. Lin, "Index selection for genetic improvement of quantitative characters," Theoretical and Applied Genetics, vol. 52, no. 2, pp. 49-56, 1978.

[16] J. D. Smith and M. L. Kinman, "The Use of Parent-Offspring Regression as an Estimator of Heritabilityl," Crop Science, vol. 5, no. 6, p. 595, 1965.

[17] K. J. Frey and T. Horner, "Heritability in standard units," Agronomy Journal, vol. 49, no. 2, pp. 59-62, 1957.

[18] Z. Fellahi, A. Hannachi, H. Bouzerzour, and A. Boutekrabt, "Line $\times$ Tester Mating Design Analysis for Grain Yield and Yield Related Traits in Bread Wheat (Triticum aestivumL.)," International Journal of Agronomy, vol. 2013, pp. 1-9, 2013.

[19] Z. Fellahi, A. Hannachi, H. Bouzerzour, S. Dreisigacker, A. Yahyaoui, and D. Sehgal, "Genetic analysis of morpho-physiological traits and yield components in F2 partial diallel crosses of bread wheat (Triticum aestivum L.)," Revista Facultad Nacional de Agronomia, vol. 70, no. 3, pp. 8237-8250, 2017.

[20] H. Chennafi, A. Aïdaoui, H. Bouzerzour, and A. Saci, "Yield response of durum wheat (Triticum durum Desf.) cultivar Waha to deficit irrigation under semi arid growth conditions," Asian Journal of Plant Sciences, vol. 5, no. 5, pp. 854-860, 2006.

[21] P. L. Spagnoletti Zeuli and C. O. Qualset, "Flag Leaf Variation and the Analysis of Diversity in Durum Wheat," Plant Breeding, vol. 105, no. 3, pp. 189-202, 1990. 
[22] M. S. McIntosh, "Analysis of combined experiments," Agronomy Journal, vol. 75, no. 1, pp. 153-155, 1983.

[23] R. G. D. Steel and J. H. Torrie, Principles and procedures of statistics, McGraw-Hill Books, New York, NY, USA, 1982.

[24] G. Acquaah, Principles of plant genetics and breeding, John Wiley and Sons, 2009.

[25] C. D. Cruz, Programa GENES: Biometria, Editora UFV, Viçosa, Brazil, 1st edition, 2006.

[26] H. F. Smith, "A discriminates function for plant selection," Annals of Eugenics, vol. 7, pp. 240-250, 1936.

[27] L. N. Hazel, "The genetic basis for constructing selection indexes," Genetics, vol. 28, no. 6, pp. 476-490, 1943.

[28] J. S. Williams, "The evaluation of a selection index," Biometrics, vol. 18, no. 3, pp. 375-393, 1962.

[29] R. C. Elston, "A Weight-Free Index for the Purpose of Ranking or Selection with Respect to Several Traits at a Time," Biometrics, vol. 19, no. 1, p. 85, 1963.

[30] J. Pesek and R. J. Baker, "Comparison of predicted and observed responses to selection for yield in wheat," Canadian Journal of Plant Science, vol. 51, no. 3, pp. 187-192, 1971.

[31] W. Subandi, A. Compton, and L. T. Empig, "Comparison of the efficiencies of selection indices for three traits in two variety crosses of corn," Crop Science, vol. 13, no. 2, pp. 184-186, 1973.

[32] N. N. Mulamba and J. J. Mock, "Improvement of yield potential of the ETO blanco maize (Zea mays L.) population by breeding for plant traits," The Egyptian Journal of Genetics and Cytology, vol. 7, no. 1, pp. 40-51, 1978 .

[33] C. D. Cruz, "GENES - A software package for analysis in experimental statistics and quantitative genetics," Acta Scientiarum Agronomy, vol. 35, no. 3, pp. 271-276, 2013.

[34] M. A. Abd El-Shafi, "Estimates of Genetic Variability and Efficiency of Selection for Grain Yield and Its Components in Two Wheat Crosses (Triticum aestivum L.)," nternational Journal of Agriculture and Crop Sciences, vol. 7, no. 2, pp. 83-90, 2014.

[35] R. W. Allard, Principles of Plant Breeding, John Wily and Sons, Inc, New York, NY, USA, 2nd edition, 1960.

[36] C. D. Cruz, A. J. Regazi, and P. C. S. Carneiro, Modelos biométricos aplicados ao melhoramento genético, UFV, Viçosa, Brazil, 4th edition, 2012.

[37] A. Mesele, W. Mohammed, and T. Dessalegn, "Estimation of Heritability and Genetic Advance of Yield and Yield Related Traits in Bread Wheat (Triticum aestivum L.) Genotypes at Ofla District, Northern Ethiopia," International Journal of Plant Breeding and Genetics, vol. 10, no. 1, pp. 31-37, 2015.

[38] B. Saleem, A. Khan, M. Shahzad, and F. Ijaz, "Estimation of heritability and genetic advance for various metric traits in seven F2 populations of bread wheat (Triticum aestivum L.)," Journal of Agricultural Sciences, Belgrade, vol. 61, no. 1, pp. 1-9, 2016.

[39] M. Yaqoob, "Estimation of genetic variability, heritability and genetic advance for yield and yield related traits in wheat under rainfed conditions," Journal of Agricultural Research, vol. 54, no. 1, pp. 1-14, 2016.

[40] C. M. Löffler and R. H. Busch, "Selection for Grain Protein, Grain Yield, and Nitrogen Partitioning Efficiency in Hard Red Spring Wheat," Crop Science, vol. 22, no. 3, p. 591, 1982.

[41] W. L. Alexander, E. L. Smith, and C. Dhanasobhan, "A comparison of yield and yield component selection in winter wheat," Euphytica, vol. 33, no. 3, pp. 953-961, 1984.

[42] J. Kumar and P. N. Bahl, "Direct and indirect selection for yield in chickpea," Euphytica, vol. 60, no. 3, pp. 197-199, 1992.
[43] R. M. DePauw and L. H. Shebeski, "An evaluation of an early generation yield testing procedure in Triticum aestivum," Canadian Journal of Plant Science, vol. 53, no. 3, pp. 465-470, 1973.

[44] M. N. Inagaki, G. Varughese, S. Rajaram, M. Van Ginkel, and A. Mujeeb-Kazi, "Comparison of bread wheat lines selected by doubled haploid, single-seed descent and pedigree selection methods," Theoretical and Applied Genetics, vol. 97, no. 4, pp. 550-556, 1998.

[45] A. Benmahammed, H. Bouzerzour, A. Djekou, and K. Hassous, "Efficacité de la sélection précoce de la biomasse chez lorge (Hordeum vulgare L.) en zone semi-aride," Sciences and Technologie, vol. C, no. 22, pp. 80-85, 2004.

[46] J. W. Mitchell, R. Baker, and D. R. Knott, "Evaluation of Honeycomb Selection for Single Plant Yield in Durum Wheat," Crop Science, vol. 22, no. 4, pp. 840-843, 1982.

[47] D. M. Lungu, P. J. Kaltsikes, and E. N. Larter, "Honeycomb selection for yield in early generations of spring wheat," Euphytica, vol. 36, no. 3, pp. 831-839, 1987.

[48] M. A. El-Morshidy, K. A. Kheiralla, M. A. Ali, and A. A. S. Ahmed, "Efficiency of pedigree selection for earliness and grain yield in two wheat populations under water stress conditions," Assiut Journal of Agricultural Sciences, vol. 37, pp. 77-94, 2010.

[49] E. E. Mahdy, "Single and Multiple Traits Selection in a Segregating Population of Wheat, Triticum aestivum L," Plant Breeding, vol. 101, no. 3, pp. 245-249, 1988. 


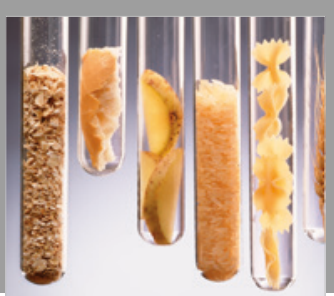

International Journal of Food Science

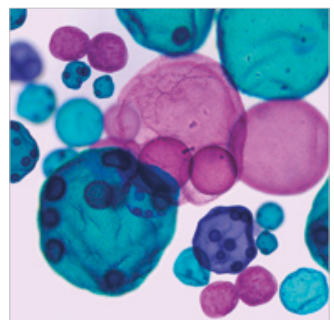

International Journal of Microbiology
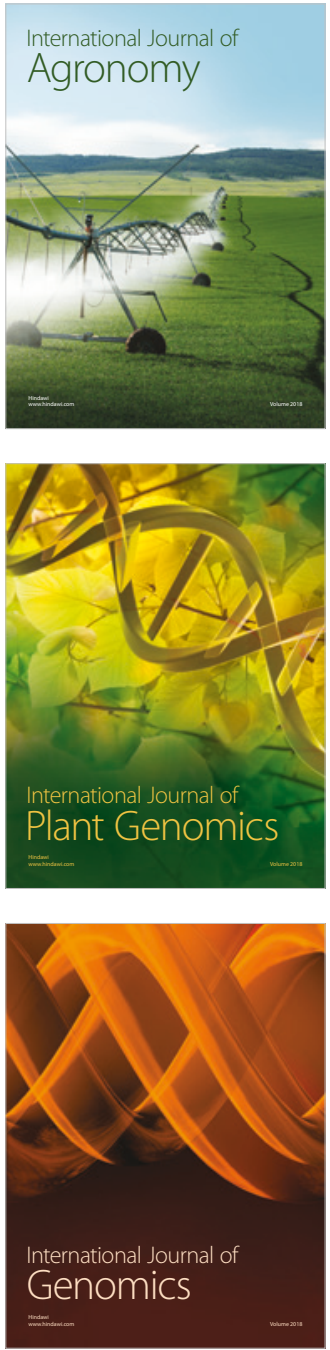

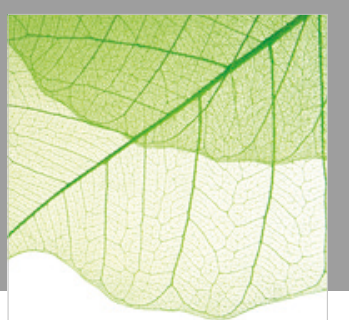

Journal of Botany
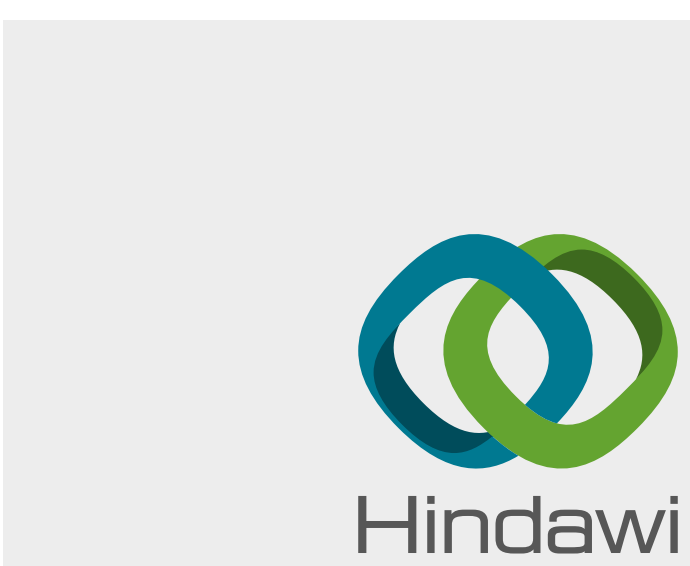

Submit your manuscripts at

www.hindawi.com
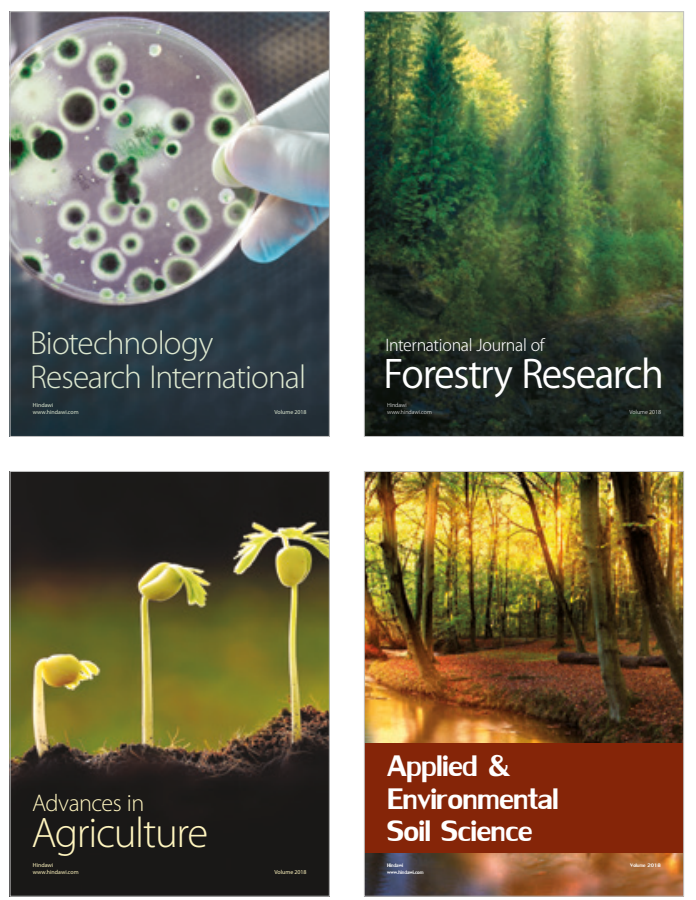

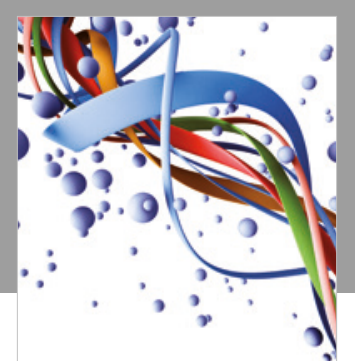

Scientifica

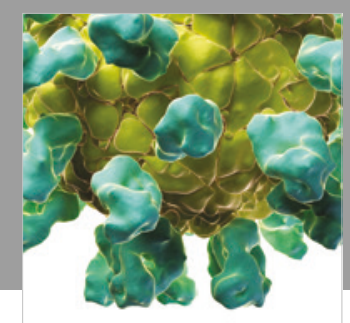

Veterinary Medicine International

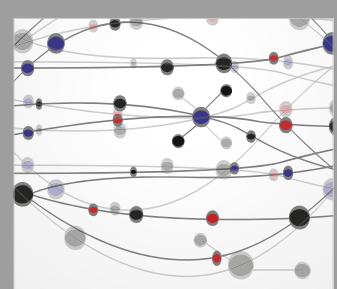

The Scientific World Journal
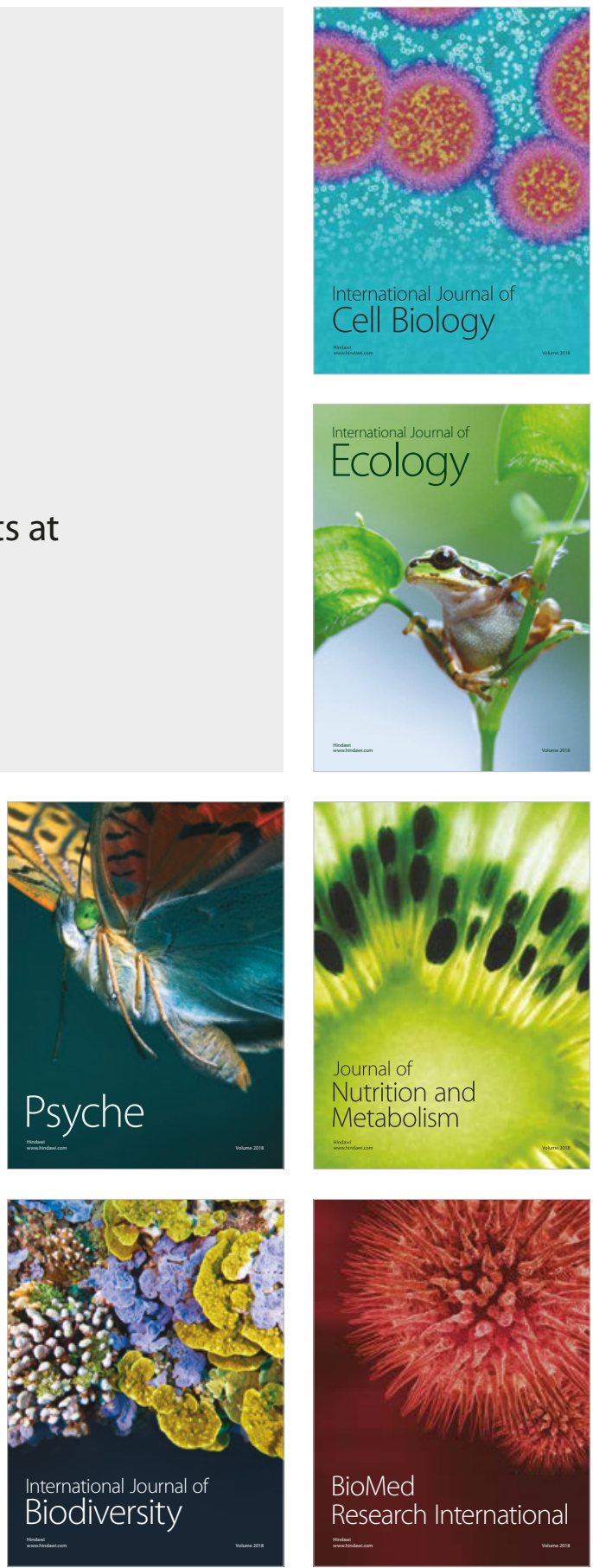